\title{
PMS2 Loss of Nuclear Expression
}

National Cancer Institute

\section{Source}

National Cancer Institute. PMS2 Loss of Nuclear Expression. NCI Thesaurus. Code C160420.

An indication that expression of PMS2 was not detected in the nuclei of cells in a sample. 